that the Council of the Royal College of Surgeons decided some time ago to establish a sub-department of biochemistry in the Department of Physiology, with the dual purpose of promoting research and of amplifying the educational facilities which the College provides for postgraduates studying the basic medical sciences. The College has long looked forward to establishing a chair of biochemistry, and is deeply indebted to Mr. Jack Cotton for his recent gift of $£ 100,000$, which will make this possible.

\section{Arrival of Methane Pioneer}

Methane Pioneer, which left the Gulf of Mexico on January 31, arrived at Canvey Island, Essex, on February 20 with an experimental cargo consisting of 2,000 tons of liquid natural gas (methane) from one of the Gulf Coast oilfields. After liquefaction, which reduces it to $1 / 600$ th of the volume occupied in gaseous form, it was loaded into five special tanks in Methane Pioneer, which is owned jointly by the Gas Council of Great Britain and Constock International Methane, Ltd., of the United States. The tanks are of aluminium with a 12 -in. insulation of balsa wood and an outer jacket of steel. The liquid will be pumped from Methane Pioneer and through an insulated pipeline from the jetty to two storage tanks, each with a capacity of about 1,000 tons of methane. One has been built for the North Thames Gas Board by the Whessoe Company, Ltd., of Darlington; the other by the A.P.V. Company, Ltd., of Crawley. Although these shore storage tanks are heavily insulated there will be a continuous boil-off of gaseous methane, and this material will be contained in a small gas-holder of the dry-sealed Wiggins type, whence it will be pumped into the mains system. Liquid methane will be vaporized by heat exchange with water or steam, and there is no intention at this stage of making use of the refrigerating capacity of the methane, which is at $-260^{\circ} \mathrm{F}$. The liquid will be converted to gas under pressure, and this pressure will be used to convey the gaseous methane into the transmission lines of the NorthThames Gas Board. A new transmission line has been laid from Canvey Island to connect with a high-pressure main already in existence between Shellhaven and Romford Works, and the gaseous methane will mix with refinery gases from the Shellhaven refinery. 'The town's gas supplied by the Board is distributed at 500 B.Th.U./ft. ${ }^{3}$, while the methane has a calorific value of 1,000 B.Th.U./ft. ${ }^{2}$, and reforming of the methane into gas of $500 \mathrm{~B}$.Th.U. $/ \mathrm{ft}^{\mathrm{a}}$ will be carried out at Romford by the Onia-Gegi catalytic process. The gas after reforming will have similar characteristics to gas normally produced from coal and will be suitable in every way for consumers' appliances, with the added advantage that it will be free from sulphur. If these trials prove successful, both technically and economically, consideration will be given to the import of liquid methane on a much larger scale. Vessels carrying some 30,000 tons will probably be required in order to secure real economy.

\section{Noise in Industry}

IN a written reply to a question about studies of the incidence and effects of noise in industrial establishments, Mr. H. Nicholls, as representing the Lord President of the Council, said in the House of Commons on February 13 that the National Physical Laboratory undertook surveys of noise for industry and advised on appropriate treatments to reduce noise inside and outside offices, factories, etc., caused by machinery and equipment used in the factory. The Laboratory also made fundamental investigations on the 'subjective loudness' of different types of noise. The Building Research Station was conducting surveys related to factory design, construction and use, and the effect of factory noise on neighbouring areas. Several grant-aided research associations were also actively interested in noise abatement although their research was mostly at an early stage. These studies were in addition to those of the Medical Research Council attempting to define the normal deterioration that occurs with age and the extent to which this may be modified by exposure to industrial noise. Papers had been and would continue to be published by the Stationery Office and in the technical press.

\section{A Register of Historic Aircraft}

A FIRST practical step towards a national aeronautical museum was taken at a meeting held at the Royal Aeronautical Society at the end of January under the chairmanship of Mr. Peter G. Masefield, president-elect of the Society. At this meeting, which was attended by twenty-six representatives of Government departments and other public bodies, it was agreed to compile a register of aircraft of major historical importance in Great Britain with the view of their preservation. The need for a national British aeronautical museum has been felt for a long time by many in the aircraft industry who are anxious that historic aircraft should be preserved. Since the Royal Aeronautical Society acquired the aircraft of the Nash Collection of Early Mechanical Transport in 1953 , so that these historic aircraft should remain in Britain, the Society has hoped that they would eventually form part of a national aeronautical museum. The decision to compile a Central National Register means that the whereabouts and condition of all historic aircraft still in Britain will be known and plans to ensure that they are not destroyed can be put in hand. The number of these valuable and irreplaceable aircraft is steadily dwindling because of a lack of national policy. A sub-committee under the chairmanship of Air Commodore A. H. Wheeler, trustee of the Shuttleworth Collection, has been formed to supervise the preparation of the Register. The Royal Aeronatical Society has already been greatly helped by many enthusiasts, but it is clear that there must be many relics still in private hands, and the Society appeals to all who possess old aeroplanes or aero-engines or who know where they are to inform the Society of their location and condition so that, if possible, they may be added to the Register. Information should be sent to Mr. A. S. C. Lumsden, Royal Aeronautical Society, 4 Hamilton Place, London, W.1.

\section{Institution of the Rubber Industry in South Africa}

THE first steps are being taken to establish a South African Section of the Institution of the Rubber Industry, consisting of a central Council in Johannesburg with branches in Johannesburg, Durban and Port Elizabeth. The aims of the new Section will be to promote the development of polymer science and technology, to encourage technical education and provide a means of association between persons engaged in the rubber industry in South Africa. South African companies and personnel engaged in rubber and plastics manufacture are invited to apply for membership of the Section. The addresses of the honorary secretaries are as follows: Johannesburg, 